\title{
The Relationship between Ownership Structures and Financial Performance Evidence from Jordan
}

\author{
Dr. Mustafa A.A. AL-Qudah \\ College of Science and Humanities, Shaqra University, Saudi Arabia, P.O.Box:1040, Al-Dawadmi 11911
}

\begin{abstract}
The aim of this study to investigate the relationship between the ownership structure such as Proportional Share of Owner equity, Proportional Share of Shareholder, Company's Growth, Company's size, and Company's Leverage from one side and financial performance represented by Return on Assets (ROA) on the other side. The population in the study Jordanian industrial companies listed at Amman Financial Market (AFM) during the period 2016-2018; The sample of the study consisted (62) company and data analysis was done using multiple linear regression analysis, (SPSS) Program. The result shows that there is significant impact of Proportional Share of Owner equity, Proportional Share of Shareholder, Company's Growth, Company's size, and Company's Leverage on financial performance. Also financial performance negatively affected by Company's Risk.
\end{abstract}

Keywords: Ownership Structure, Return on Assets, Capital Structure, Financial Performance.

DOI: $10.7176 /$ RJFA/10-24-15

Publication date: December $31^{\text {st }} 2019$

\section{Introduction:}

The variables postulated by theories of capital structure are subject of numerous empirical studies that support decisions in the selection of sources of financing. The entity's capital structure should be subordinated to the basic objective of the business entity's functioning on the market, which is to maximize its value for shareholders. In practice, this is not a simple task, because there is large number of factors affecting the structure of capital.

The relationship between companies ownership structure and their financial performance accounted for the attention of many researchers in previous literature for several decades, these studies began by taking issues related to conflict of interest between owners and managers so-called agency problem, as pointed out by the study (Jensen and Meckling, 1976), where the focus of discussion in these two studies related to Agency Theory, which shows the conflict of interest between decision-makers in the institutions and their shareholders. The two studies question whether the management, in fact, act on the interest of owners and seek to achieve their goals when making investment and financing decisions especially in large companies.

We must know that the performance of the company affects the ownership structure and the ownership structure affects the performance of the company, since the difference between the internal expectations and the market external expectations about the company's performance creates an incentive for the management to change the ownership structure of its shares. Therefore, we conclude that the growth of the internal ownership must be taken into account when looking at the relationship between ownership structure and performance, and not to take the internal growth leads to biased deviation (Demsetz and Villalonga, 2001). Multinational Corporations (MNCs) are generally financed with a mixture of internal debt and equity from the parent corporation. Yet, financial theory has relatively little to say regarding the capital structure.

In this paper, I will illustrate the relationship between ownership structure and some financial variables which affect financial performance of Jordanian industrial companies.

\section{Study Problem:}

Financial performance is the primary goal of all companies. Without good financial performance, business will not survive in the long run. Research on financial performance, therefore, is critical because it will enable us to identify the particular mix of regulations and supervisory standards promoting well-functioning companies and thus provide better guidance to policy makers on appropriate reforms.

Higher capitals often supposed to be costly, implying that higher capital reduces profitability, but according to the tradeoff theory, it may also reduce risk and hence the premium demanded to compensate investors for the costs of bankruptcy. According to conventional corporate finance theories, a company in equilibrium will desire to hold a privately optimal level of capital that just trades off costs and benefits, implying a zero relationship at 
the margin. However, capital requirement imposed by regulators, force companies to hold capital in excess of their private optimal and hence force companies above their internal optimal capital ratio (Miller, 1988). Studies on the relationship between firm's financial structure and financial performance have yielded mixed results. It is widely acknowledged that a well-structured company, defined by its supervisory practices, risk taking, and governance, promotes greater financial performance and economic stability.

Therefore, the Study Problem was to study the relationship between financial structure and financial performance of Jordanian industrial companies listed at Amman Financial Market (AFM), and it can be summarized to answer the following questions:

1. What is the relationship between Proportional Share of owner equity and financial performance of Jordanian industrial companies?

2. What is the relationship between Proportional Shareholder and financial performances of Jordanian industrial companies?

3. What is the relationship between company's risk and financial performance of Jordanian industrial companies?

4. What is the relationship between company's size and its financial performance of Jordanian industrial companies?

5. What is the relationship between company's growth and financial performance of Jordanian industrial companies?

6. What is the relationship between financial leverage and the financial performance of Jordanian industrial companies?

\section{Objectives of the Study:}

The general objective of the study to identify the relationship between ownership structure and financial performance of Jordanian industrial companies listed at (AFM) with the following specific objectives.

1. To assess the relationship between Proportional Share of owner equity and financial performance of Jordanian industrial companies

2. To assess the relationship between Proportional Shareholder and financial performances of Jordanian industrial companies.

3. To assess the relationship between company's risk and financial performance of Jordanian industrial companies.

4. To assess the relationship between company's size and its financial performance of Jordanian industrial companies.

5. To assess the relationship between company's growth and financial performance of Jordanian industrial companies.

6. To assess the relationship between financial leverage and the financial performance of Jordanian industrial companies.

\section{Literature Review:}

The capital structure has been of interest for researchers in the field of financial theory for over 70 years. At the beginning of capitalism phase, the dominant form of companies was the small businesses that include both the ownership and management in one company. In the nineteenth century, the industrial revolution, and the changing technology used in production, the size of companies was increased, so that is no longer the same family, or a group of managers able to create a company individually, and the traditional ownership which lasted four decades was disappeared and began the era of separation of ownership from management.

Previous literature has revealed that managerial ownership in the company is a vital factor that alleviates agency conflicts and promotes company performance (Abor and Biekpe, 2007); (Al-Khouri, 2006); (Gedajlovic\& Shapiro, 2002); (Hiraki et al., 2003); (Kren\& Kerr, 1997). For example, (Kren\& Kerr, 1997) argued that increasing managerial ownership is the important tool to promote improved performance of the company. (Kumar \& Singh, 2013) investigated the relationship between managerial ownership and firm performance, and they found that there is a significant positive relationship between these two variables. At the international and local levels, in both developed and developing countries, the study conducted by (Alabdullah et al. 2014a, b) chose market share to represent firm financial performance but in its relationship with board characteristics. In 
the Jordanian context, a study conducted by (Zeitun, 2009) investigates the impact of government ownership and ownership concentration on firm performance and the findings revealed that they played a significant role in the firm performance. In the Bahrain context, (Al-Matari et al., 2014) examine the relationship between size of audit committee, independence of audit committee and size of executive committee, and firm performance, the finding revealed a positive relationship between them and firm performance.

On the other hand, there are other previous studies that revealed a negative relationship between managerial ownership mechanism and firm performance, such as (Acharya \&Bisin, 2009). Some previous studies (Demsetz and Villalonga, 2001) demonstrate that there is no association between managerial ownership and firm performance.

4.1 (Mursalim, Mika, \&Kusuma (2017) the study investigates the capital structure determinants of the firms in Indonesia, Malaysia, and Thailand. In their study, the investigated variables are profitability, firm size, growth opportunity, volatility, gross domestic product (GDP rate), inflation rate, and corporate governance. Using path analysis of two-multiple regressions, the leverage behavior is examined for the firm samples consisting of 94 Indonesian firms, 153 Malaysian firms, and 74 Thailand firms for the period 2008-2012. The results show that company's profitability, firm size and volatility have dominant and consistent roles in explaining the variation of the capital structure. The variables of growth opportunity, gross domestic product, inflation rate and corporate governance in general influence the variation of the capital structure. Furthermore, the capital structure of firms was significantly related to the firm performance.

4.2 (Bhatia, \&Sitlani (2016) the study investigates the "Determinants of Capital Structure of Small Firms: Empirical Evidence from Pharmaceutical Industry in Indore", key determinants of financing decisions of firms at national and international level. Standing on this premise, the research work has attempted to empirically validate the key internal financial determinants of pharmaceutical firms in Indore. Drawing a sample of 29 firms over a period of 6 years, data analysis was conducted applying Panel Data Regression Model using Strata software. The results of the study revealed that Profitability, Asset Tangibility and Size of the firm are important determinants of capital structure in case of the smaller firms.

4.3 (Cahyonod Chawla (2019) the purpose of the study was to assess the effectiveness of "Capital Structure Determinants of Indonesian Mining Companies: An Evidence from Balanced Panel Data". The financial structure is a vital decision in financing policy of the companies, the study analyses the firm-specific variables, which influence leverage determination among the Indonesian Mining firms. This study also identify whether the relationships between firms' debt ratios and determinants can be explicated by the capital structure theories.

The leverage is assessed by measurements, long-term as well as short-term debt ratio. Meanwhile, the predictors include tangibility, flexibility, liquidity, profitability, firm size, sales growth, retained earnings, free cash flow, and firm age. The balanced panel data were taken from 22 sample firms from 2010 to 2015 to analyze the relationship between leverage and 9 determinants.

Result of analysis indicates that tangibility positively influence long-term leverage, financial flexibility positively affects total and long-term leverage, liquidity is negatively associated with total and short-term debt, firm size influences positively on long-term leverage but negatively on short-term debt, retained earning negatively on total and long-term leverage, free cash flow positively affects short-term leverage, and age of firms is positively associated with short-term debt. In short, these relationships sustain the applicability of capital structure theories among Indonesian mining companies.

4.4 (Palacios, A. , Carrillo, p. \& ,Guzman, $M$ (2019) The objective of the empirical study is to determine the effects of the capital structure in the performance of the S Mexico's manufacturing companies, specifically; the work was done with a sample of 221 manufacturing located in Mexico. The obtained results through the empirical testing of a structural equation modeling provide empirical evidence that the internal financing sources influence significantly and positively the performance. Similarly, it was found that the external sources of financing have a positive influence, but not significantly in performance, which draws attention to the importance of these companies carefully plan their capital structure, giving preference to the internal financing sources. 


\section{Capital structure}

Capital structure theory explains whether there is an influence of changes in capital structure on the company financial performance, if the company replaces part of its own capital with debt or vice versa, whether the company financial performance will change. The best capital structure will be obtained, Capital structure that can maximize company financial performance.

\subsection{Components of capital Structure}

Capital structure of a company generally consists of several components: (1) Equity; Equity is capital that comes from the owner of the company and which is embedded in the company. Owned capital comes from internal sources and external sources. Internal sources come from profits, while external sources come from capital derived from company owner's shares. (2) Retained Earnings, cumulative profit after tax since the company was established and not distributed as dividends to shareholders. (3) Long-term debt is debt with a long term, generally more than one year.

\subsection{Theory of capital structure}

There were several theories that discussed capital structure; the researcher will concentrate on the most popular theories.

\subsubsection{The traditional theory}

The traditional theory assumes that up to leverage certain, the risk of the company does not change. However, after leverage or certain debt ratios, debt costs and capital costs increase.

\subsubsection{Modigliani and Miller (MM)}

Modigliani and Miller (1958) started the modern theory of capital structure, which assumes a perfect market, where insiders and outsiders have symmetric information; no transaction costs, bankruptcy costs or taxation distortions; equity and debt choices became irrelevant and internal and external capital can be substituted. Later the revised MM model (Modigliani \& Miller, 1963) suggested that the optimal structure occurred because of the tax-shield benefit of using debt financing over equity. Fama and French (1998) studied the tax model of the MM theorem and concluded that companies that are more profitable tend to use more debt rather than equity. The MM theorem has given rise to many more modern theories of capital structure.

\subsubsection{Agency theory}

Agency costs refer to costs associated with resolving conflicts among managers, bondholders, and shareholders. The agency costs based theory states that a firm's capital structure is determined by agency costs, which includes the costs of debt and equity issuing. Jensen and Meckling (1976) claimed that more debt issue could lead to conflict between shareholders (through managers) and bondholders, since managers may invest in high-risk projects that yield high returns to shareholders, but increase the cost of failure to bondholders, because of shareholders' limited liability. More equity issues, on the other hand, could lead to conflict between shareholders and management due to high levels of free cash flow. Managers may select short-term projects rather than profitable long-term projects due to results that may come early and enhance their reputation quickly. Managers may prefer less risky investments and lower debt levels to reduce the chance of bankruptcy, and this may diverge from shareholders' interest in maximizing the firm's value (Jensen \& Meckling, 1976).

This theory states that in a company there will be a conflict of interest between the parties involved in it, this conflict occurs because of the interests of the owner and management. Management does not always act in accordance with the interests of the owner's; as a result, managers can use company resources more freely.

\subsubsection{Static Trade-off Theory}

The static trade-off theory was proposed by Modigliani and Miller (1958) based on tax-shelter benefits, bankruptcy costs, and agency costs, where there is no offsetting cost of debt; thus, firms can solely use debt financing in their capital structures. Later, Kraus and Litzenberger (1973) proposed an optimal capital structure involving a trade-off between the costs and benefits of debt financing. In the trade-off model, debt financing has one important advantage over equity; the interests provide tax-shelter benefit while equity income is subject to 
corporate tax. However, debt increases financial risks so that debt financing is not cheaper than equity financing. In static trade-off theory, managers must balance the costs and benefits of borrowings, and maintain an appropriate debt level to maximize the firm value.

\subsubsection{Signaling theory}

Signaling theory (MM) assumes that everyone both investors and managers have the same information about the company's prospects. This is referred to as symmetric information. However, in reality managers often have better information than outside investors. This is referred to as asymmetric information and has an important influence on optimal capital structure. To illustrate assume that there are two alternatives, the first, where a company manager knows that prospects will greatly benefit companies Favorable alternative, and the second, where the manager knows that the future looks unprofitable for the company Unfavorable alternative.

\subsubsection{Pecking order theory}

The pecking order theory was developed by Myers and Majluf (1984). The pecking order theory states that a firm follows a hierarchy of financing choices ranging from internal to external sources. The theory relies on the assumption that adverse selection costs result from issuing risky securities incurred because of either asymmetric information, managerial optimism, or both. To minimize adverse selection costs, firms prefer internal over external sources of funds. If the firms need external funds, the first preference is to issue debt.

6. Operational definition of variables: Financial performance measures the success of the company and its ability to survive; it can be measured by different ratios such as: Return on assets (ROA), Return on equity (ROE), and Return on Investments (ROI).

6.1 Financial Performance: Financial performance was measured by ROA in this study, ROA calculated by dividing net income before deduction of interest by net assets (Kaplan, et al., 1998).

If this ratio is low, it reflects low financial performance of the company, but if it is high, it reflects the efficiency and effectiveness of the company's operational policies.

To test the effect of ownership structure on the financial performance, it is assumed that the financial performance of companies which is measured by ROA depends on a number of explanatory financial variables in addition to the structure of the ownership. Variables used in the study are:

The dependent variable is financial performance measured by ROA calculated by dividing net income before deduction of interest by net assets. The independent variables include, Proportional Share of Owners Equity, Proportional Share of Shareholder, Company Risk, Company Growth, Company Size, and Leverage Ratio.

6.2 Proportional Share of Owners Equity: Calculated by the percentage amount of Shares of Owners Equity in the ownership structure.

6.3 Proportional Share of Shareholder: Calculated by the percentage amount of Shares of Shareholder in the ownership structure.

6.4 Company Risk: Calculated by the standard deviation of Earning before Interest and Tax (EBIT).

6.5 Company Size: Size of the companies is widely used in the previous literature to test the effect of ownership structure on the performance; in this study, company size was measured by using total assets.

6.6 Company Growth: Calculated as total asset of the current year less total assets of the previous year, divided by total asset of the previous year.

6.7 Leverage Ratio: Company's leverage ratio affects the company's profitability. Financial leverage means the use of long-term debt to finance the company's operations to achieve the greatest possible profitability (Brailsford, et. al, 2002), in this study it is measured by dividing the total liabilities to total assets.

\section{Study methodologies:}

To achieve the objectives of the study the researcher followed the descriptive and analytical statistical method. The researcher depended on gathering primary and secondary data; Secondary sources were literature review 
such as journals, books, and internet. The instrument used for the collection of the primary data was financial statements for Jordanian industrial companies listed at (AFM).The random sampling method was adopted in this study. To include in the sample, a firm must meet the following criteria: (a) Publishing annual financial statements (b) Having positive earnings (c) actively traded in the market.

These criteria results in 62 corporations. The regression formula technique (OLS) was used to test the hypotheses of the study by using data Published in the financial statements for the years ended December 31, 2016-2018.

The abbreviations of the independent variables; company risk, Proportional Share of Shareholder, Proportional Share of Owners Equity, Company Growth, Company Size, and Leverage Ratio, illustrated in the following table.

Table (1) Abbreviation of the study

\begin{tabular}{|l|l|}
\hline Company's Risk & Comp. Risk \\
\hline Proportional Share of Shareholder & Shareholder Prop. \\
\hline Proportional Share of Ownership & Owner Prop. \\
\hline Company's Growth & Comp. Growth \\
\hline Company's Size & Comp. size \\
\hline Company's Leverage & Lev. \\
\hline
\end{tabular}

7.1 Study model: Based on the research objectives and literature review, the researcher developed the study model as shown in Figure 1.

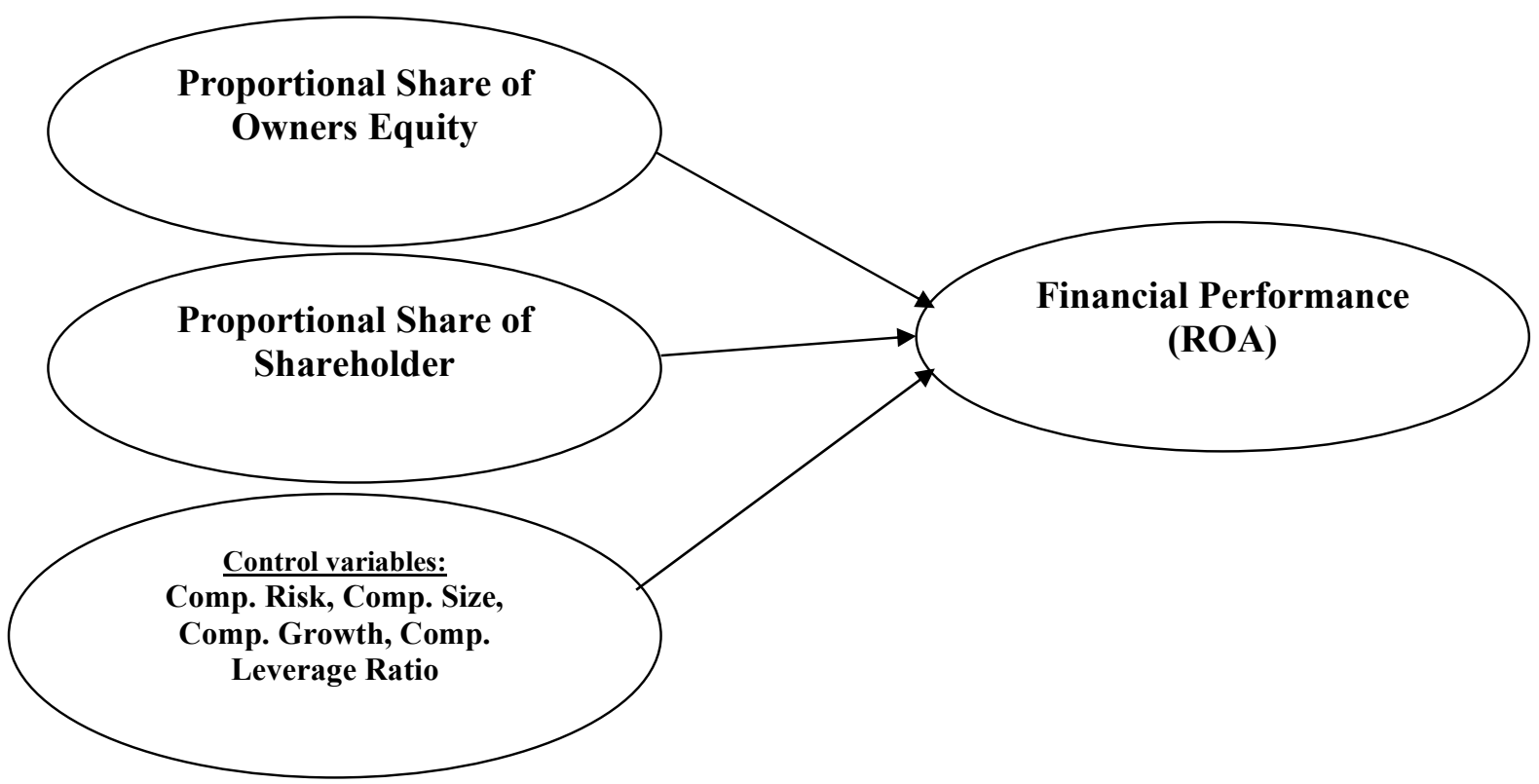

Figure 1

Study model

\subsection{Hypothesis of the Study:}

Based on the literature review, research problem, and research objectives, the researcher develops the following hypothesis:

H1: There is no statistically relationship between owner equity ownership and the financial performance of Jordanian industrial companies.

H2: There is no statistically relationship between Shareholder ownership and the financial performances of Jordanian industrial companies.

H3: There is no statistically relationship between company's risk and its financial performance of Jordanian industrial companies.

H4: There is no statistically relationship between company's size and financial performance of Jordanian industrial companies. 
H5: There is no statistically relationship between company's growth and its financial performance of Jordanian industrial companies.

H6: There is no statistically relationship between company's financial leverage and the financial performance of Jordanian industrial companies.

\section{Data Analysis}

To achieve the objectives of the study, and to answer the research questions, statistical method (SPSS) was used to test the hypothesis of the study.

\subsection{Descriptive statistics}

The study sample consisted of 62 Industrial companies listed in Amman Financial Market; the data was collected from the reported financial statements of each company. Table (2) presents the descriptive statistics for variables of the study.

Table (2) shows that The mean for ROA equal 10.098, with a maximum value of equal 13.084 and minimum value of 12.969, the mean for Owner equity ownership equal 16.195, with maximum value of 17.093 and minimum value of 15.955 , the mean of Shareholder ownership equal 15.878 with maximum value of 16.490 and minimum value of 14.125 , the mean for Company's risk equal -3.380 with maximum value of -4.670 and minimum value of -5.050 , the mean for Company's size which was measured by total assets equal 24,277,913, with maximum value of $105,550,623$ and minimum value of $1,112,494$, the mean for Company's growth equal 2.430 with maximum value of 5.045 and minimum value of 4.215 , and the mean for Leverage equal 1.380 with maximum value of 1.670 and minimum value of 1.050 , the above results seem reasonable and within the normal range.

Table (2): Descriptive Statistics

\begin{tabular}{|l|c|c|c|c|c|c|}
\hline & $\mathrm{N}$ & Minimum & Maximum & Mean & Std. Dev. & Variance \\
\hline ROA & 62 & 12.969 & 13.084 & 10.098 & 1.18 & 1.41 \\
Owner equity ownership & 62 & 15.955 & 17.093 & 16.195 & 1.44 & 2.11 \\
Shareholder ownership & 62 & 14.125 & 16.490 & 15.878 & 1.47 & 2.16 \\
Company's risk & 62 & -5.050 & -4.670 & -3.380 & 1.14 & 1.30 \\
Company's size & 62 & 1112494 & 105550623 & 24277913 & 1.01 & 1.03 \\
Company's growth & 62 & 4.215 & 5.045 & 2.430 & 1.25 & 1.57 \\
Leverage & 62 & 1.050 & 1.670 & 1.380 & 1.11 & 1.23 \\
\hline
\end{tabular}

\subsection{Test hypotheses of the study: Regression Model- Pearson correlation:}

To test the relation between the independent variables and dependent variable of the study, Pearson correlation analysis was used. In general, if the correlation coefficient between independent variables more than $(80 \%)$ it suggests problem of multicollinearity.

According to Pearson correlation results presented in table (3) which illustrates that there is significant statistical positive correlation between ROA and Proportional Share of Owner equity, Proportional Share of Shareholder, Company's Growth, Company's size, and Company's Leverage at 1\% level, with coefficient values 0.606, 0.550, $0.555,0.599,0.522$, respectively for the previous mentioned variables, which mean that the independent variables; Proportional Share of Owner equity, Proportional Share of Shareholder, Company's Growth, Company's size, and Company's Leverage, affect positively the dependent variable ROA, if any of these variable increase ROA will increase, which means that financial performance will increase.

This does not support the hypothesis of the study; H1, H2, H4, H5, H6 which states that There is no statistically relationship between the independent variables (Proportional Share of Owner equity, Proportional Share of Shareholder, Company's Growth, Company's size, and Company's Leverage) and the financial performance of Jordanian industrial companies, therefore the null hypothesis will be rejected and the substitute hypothesis will be adopted. Also there is significant statistical negative correlation between ROA and Company's Risks at $1 \%$ level, with coefficient value 0.519 , which mean that the independent variable Company's Risks, affect negatively the dependent variable ROA, if Company's Risks increases ROA will decrease, which mean that financial performance will decrease. 
This result support the hypothesis of the study; H3 which states that there is no statistically relationship between Company's Risks and financial performance of Jordanian industrial companies, therefore the null hypothesis will be adopted.

Table (3) Pearson correlation

\begin{tabular}{|c|c|c|c|c|c|c|c|c|}
\hline & & $\mathrm{ROA}$ & Owner Prop. & Shareholder Prop. & Comp. Risk & $\begin{array}{l}\text { Comp. } \\
\text { Growth }\end{array}$ & Comp. Size & Lev \\
\hline$\overline{\mathrm{ROA}}$ & $\begin{array}{l}\text { Pearson Correlation } \\
\text { Sig. (2-tailed) } \\
\mathrm{N}\end{array}$ & $\begin{array}{c}1 \\
62\end{array}$ & $\begin{array}{c}0.606^{* * *} \\
0.001 \\
62\end{array}$ & $\begin{array}{c}0.550^{* * *} \\
0.004 \\
62\end{array}$ & $\begin{array}{c}-0.519^{* * *} \\
0.000 \\
62\end{array}$ & $\begin{array}{c}0.555^{* * *} \\
.001 \\
62\end{array}$ & $\begin{array}{c}0.599^{* * *} \\
0.009 \\
62\end{array}$ & $\begin{array}{c}0.522^{* * *} \\
0.002 \\
62\end{array}$ \\
\hline Owner Prop. & $\begin{array}{l}\text { Pearson Correlation } \\
\text { Sig. (2-tailed) } \\
\mathrm{N}\end{array}$ & $\begin{array}{c}0.606^{* * *} \\
0.001 \\
62\end{array}$ & $\begin{array}{c}1 \\
62 \\
\end{array}$ & $\begin{array}{c}0.518^{* * *} \\
0.000 \\
62\end{array}$ & $\begin{array}{c}-0.582^{* * *} \\
0.000 \\
62\end{array}$ & $\begin{array}{c}0.604^{* *} \\
0.063 \\
62\end{array}$ & $\begin{array}{c}0.619^{* *} \\
0.041 \\
62\end{array}$ & $\begin{array}{c}0.523^{*} \\
0.07 \\
62 \\
\end{array}$ \\
\hline Shareholder Prop. & $\begin{array}{l}\text { Pearson Correlation } \\
\text { Sig. (2-tailed) } \\
\mathrm{N}\end{array}$ & $\begin{array}{c}0.550^{* * *} \\
0.004 \\
62 \\
\end{array}$ & $\begin{array}{c}0.518^{* * *} \\
0.000 \\
62 \\
\end{array}$ & $\begin{array}{r}1 \\
62 \\
\end{array}$ & $\begin{array}{c}-0.579^{* *} \\
0.014 \\
62\end{array}$ & $\begin{array}{c}0.568^{* *} \\
0.075 \\
62 \\
\end{array}$ & $\begin{array}{c}0.531^{* *} \\
0.034 \\
62 \\
\end{array}$ & $\begin{array}{c}0.516^{*} \\
0.085 \\
62 \\
\end{array}$ \\
\hline Comp. Risk & $\begin{array}{l}\text { Pearson Correlation } \\
\text { Sig. (2-tailed) } \\
\text { N }\end{array}$ & $\begin{array}{c}-0.519^{* * *} \\
0.000 \\
62 \\
\end{array}$ & $\begin{array}{c}-0.582^{* * *} \\
0.000 \\
62 \\
\end{array}$ & $\begin{array}{c}-0.579^{* *} \\
0.014 \\
62 \\
\end{array}$ & $\begin{array}{r}1 \\
62 \\
\end{array}$ & $\begin{array}{c}-0.570^{\text {**** }} \\
0.000 \\
62 \\
\end{array}$ & $\begin{array}{c}-0.645^{* * *} \\
0.000 \\
62 \\
\end{array}$ & $\begin{array}{c}-0.570^{*} \\
0.06 \\
62 \\
\end{array}$ \\
\hline Comp. Growth & $\begin{array}{l}\text { Pearson Correlation } \\
\text { Sig. (2-tailed) } \\
\text { N }\end{array}$ & $\begin{array}{c}0.555^{* * *} \\
.001 \\
62\end{array}$ & $\begin{array}{c}0.604^{* *} \\
0.063 \\
62\end{array}$ & $\begin{array}{c}0.568^{* *} \\
0.075 \\
62\end{array}$ & $\begin{array}{c}-0.570^{* * *} \\
0.000 \\
62\end{array}$ & 62 & $\begin{array}{c}0.514^{* * *} \\
0.000 \\
62\end{array}$ & $\begin{array}{c}0.538^{*} \\
0.054 \\
62\end{array}$ \\
\hline Comp. Size & $\begin{array}{l}\text { Pearson Correlation } \\
\text { Sig. (2-tailed) } \\
\mathrm{N}\end{array}$ & $\begin{array}{c}0.599^{* * *} \\
0.009 \\
62\end{array}$ & $\begin{array}{c}0.619^{* *} \\
0.041 \\
62\end{array}$ & $\begin{array}{c}0.531^{* *} \\
0.034 \\
62\end{array}$ & $\begin{array}{c}-0.645^{* * *} \\
0.000 \\
62\end{array}$ & $\begin{array}{c}0.514^{* * *} \\
0.000 \\
62\end{array}$ & $\begin{array}{l}1 \\
62\end{array}$ & $\begin{array}{c}0.516^{*} \\
0.059 \\
062\end{array}$ \\
\hline Lev. & $\begin{array}{l}\text { Pearson Correlation } \\
\text { Sig. (2-tailed) } \\
\mathrm{N}\end{array}$ & $\begin{array}{c}0.522^{* * *} \\
0.002 \\
62\end{array}$ & $\begin{array}{c}0.523^{*} \\
0.07 \\
62\end{array}$ & $\begin{array}{c}0.516^{*} \\
0.085 \\
62\end{array}$ & $\begin{array}{c}-0.570^{*} \\
0.06 \\
62\end{array}$ & $\begin{array}{c}0.538^{*} \\
0.054 \\
62\end{array}$ & $\begin{array}{c}0.516^{*} \\
0.059 \\
62\end{array}$ & 62 \\
\hline
\end{tabular}

ROA: Return on Assets

$* * *$. Correlation is significant at the $1 \%$ level (2-tailed), if $0.000 \leq \alpha \leq 0.01$

**. Correlation is significant at the $5 \%$ level (2-tailed) ), if $0.01<\alpha \leq 0.05$

*. Correlation is significant at the 0.10 level (2-tailed), if $0.05<\alpha \leq 0.10$

Table (4), lists the six independent variables that are entered into the regression model, it illustrates that the value of $\left(\mathrm{R}^{2}\right)$ of 0.844 , and the regression results show a relatively high value for the adjusted $\left(\mathrm{R}^{2}\right)$ of 0.715 which means that the percentage of total variation in the dependent variable (financial performance) is explained by the independent variables (Proportional Share of Owner equity, Proportional Share of Shareholder, Company Growth, Company's size, Company's Leverage and Company's risk) of 71.5\%, which consider best.

Table (4) Regression Model Summary

\begin{tabular}{|l|l|l|l|l|}
\hline Model & $R$ & R Square & $\begin{array}{l}\text { Adjusted } \\
\text { Square }\end{array}$ & $\begin{array}{l}\text { Std. Error of the } \\
\text { Estimate }\end{array}$ \\
\hline 1 & $0.844^{\mathrm{a}}$ & 0.759 & 0.715 & .162754 \\
\hline
\end{tabular}

Table (5) illustrates $F$ value of (8.721) which is statistically significant at $1 \%$ levels which means that the regression model is significant.

Table (5) ANOVA Table

\begin{tabular}{|ll|l|l|l|l|l|}
\hline Model & & Sum of Squares & df & Mean Square & F & Sig. \\
\hline 1 & Regression & 1.748 & 6 & .291 & 8.721 & $.000^{\text {a }}$ \\
& Residual & 1.169 & 35 & .033 & & \\
& Total & 2.917 & 41 & & & \\
\hline
\end{tabular}

Table (6) shows the results of multiple regression analysis, which was used to know the impact of each independent variable (Proportional Share of Owner equity, Proportional Share of Shareholder, Company's Growth, Company's size, Company's Leverage and Company's risk) on the dependent variable (ROA). 
Table (6) Multiple Regression Coefficients Results

\begin{tabular}{|c|c|c|c|c|c|c|}
\hline & \multirow[b]{2}{*}{ Model } & \multicolumn{2}{|c|}{ Unstandardized Coefficients } & \multirow{2}{*}{$\begin{array}{c}\begin{array}{c}\text { Standardized } \\
\text { Coefficients }\end{array} \\
\text { Beta }\end{array}$} & \multirow[b]{2}{*}{$\mathrm{T}$} & \multirow[b]{2}{*}{ Sig. } \\
\hline & & $\mathrm{B}$ & Std. Error & & & \\
\hline \multirow[t]{7}{*}{1} & (Constant) & 0.225 & 0.190 & & 1.108 & 0.255 \\
\hline & Owner Prop. & 6.281 & 0.000 & 0.740 & 1.635 & 0.005 \\
\hline & Shareholder Prop. & 5.285 & 0.000 & 0.630 & 1.635 & 0.004 \\
\hline & Comp. Risk & 1.935 & 0.000 & 1.708 & 2.649 & 0.005 \\
\hline & Comp. Growth & 0.095 & 0.035 & 1.719 & 2.643 & 0.002 \\
\hline & Comp. size & 0.570 & 0.176 & 1.597 & 3.262 & 0.002 \\
\hline & Lev. & 9.304 & 0.000 & 1.507 & 6.204 & 0.000 \\
\hline
\end{tabular}

a. Dependent Variable: ROA

According to the regression results presented in table (6) the independent variables (Proportional Share of Owner equity, Proportional Share of Shareholder, Company's Growth, Company's size, Company's Leverage) have significant impact on the dependent variable ROA at significant level of $1 \%$,. Also the independent variable (Company's risk) has significant impact on the dependent variable ROA at significant level of $1 \%$, which emphasize the results in table (5).

\subsection{Results of Data Analysis: The results of the analysis show that:}

1- There is significant statistical positive correlation between ROA and Proportional Share of Owner equity, Proportional Share of Shareholder, Company's Growth, Company's size, and Company's Leverage at 1\% level, which mean that the independent variables; Proportional Share of Owner equity, Proportional Share of Shareholder, Company's Growth, Company's size, and Company's Leverage, affect positively the dependent variable financial performance. If any of these variables increase, financial performance of Jordanian industrial companies will increase.

2- Also there is significant statistical negative correlation between financial performance and Company's Risks at $1 \%$ level, which mean that the independent variable Company's Risks affect negatively the dependent variable financial performance. If Company's Risks increased financial performance will decrease.

\section{References}

Jensen M.C., Meckling W.H., 1976, Theory of the firm: Managerial behavior, agency cost and ownership structure, Journal of Financial Economics, vol. 3.

Fama, E., \& French, K. (1998). Taxes, Financing Decisions, and Firm Value. The Journal of Finance, 53(3), 819-843

Kraus, A., \& Litzenberger, R. (1973). A State-Preference Model of Optimal Financial Leverage. The Journal of Finance, 28(4), 911-922.

Jensen, M., \& Meckling, W. (1976). Theory of the Firm: Managerial Behavior, Agency Costs, and Ownership Structure. Journal of Financial Economics, 3(4), 305-360.

Myers, S., \& Majluf, N. (1984). Corporate Financing and Investment Decisions when Firms have Information that Investors Do Not Have. Journal of Financial Economics, 13(2), 187-221.

Mishkin, F. (1999). Lessons from the Asian Crisis. Journal of International Money and Finance, 18, 709723. Modigliani, F., \& Miller, M. (1958). The Cost of Capital, Corporate Finance and the Theory of Investment. The American Economic Review, 48(3), 261-297.

Modigliani, F., \& Miller, M. (1963). Corporate Income Taxes and the Cost of Capital: A Correction. The American Economic Review, 53(3), 433-443.

Miller, M.H. (1988). The Modigliani-Miller propositions after thirty years. Journal of Economic Perspectives, 2(4), 99-120.

Alabdullah, T.T.Y., Yahya, S. and Ramayah, T. (2014a), "Corporate governance development: new or old concept", European Journal of Business and Management, Vol. 6 No. 7, pp. 312-315. 
Alabdullah, T.T.Y., Yahya, S. and Ramayah, T. (2014b), "Corporate governance mechanisms and Jordanian companies' financial performance”, Asian Social Science, Vol. 10 No. 22, p. 247.

Abor, J. and Biekpe, N. (2007), “Corporate governance, ownership structure and performance of SMEs Ghana: implications for financing opportunities", Corporate Governance, Vol. 7 No. 3, pp. 288-300.

Al-Khouri, R. (2006), "Corporate governance and firm's value in emerging markets: the case of Jordan”, Journal of Transnational Management, Vol. 12 No. 1, pp. 25-49.

Al-Matari, E.M., Al-Swidi, A.K. and Fadzil, F.H.B. (2014), "Audit committee characteristics and executive committee characteristics and firm performance in Oman: empirical study", Asian

Social Science, Vol. 10 No. 12, p. 98.

Gedajlovic, E. and Shapiro, D.M. (2002), “Ownership structure and firm profitability in Japan”, Academy of Management Journal, Vol. 45, No. 3, pp. 565-575.

Kren, L. and Kerr, J.L. (1997), "The effects of outside directors and board shareholdings on the relation between chief executive compensation and firm performance", Accounting and Business Research, Vol. 27 No. 4, PP. 297-309.

Kumar, N. and Singh, J.P. (2013), "Effect of board size and promoter ownership on firm value: some empirical findings from India", Corporate Governance, Vol. 13 No. 1, PP. 88-98.

Zeitun, R. (2009), "Ownership structure, corporate performance and failure: evidence from panel data of emerging market the case of Jordan”, Corporate Ownership \& Control, Vol. 6 No. 4, pp. 96-114.

Demsetz, H. and Villalonga, B. (2001), “Ownership structure and corporate performance”, Journal of Corporate Finance, Vol. 7 No. 3, PP. 209-233.

Acharya, V.V. and Bisin, A. (2009), "Managerial hedging, equity ownership, and firm value", The RAND Journal of Economics, Vol. 40 No. 1, PP. 47-77.

Mursalim, M., Mika, M.andKusuma H., (2017), "Capital structure determinants and firms Performance: empirical evidence from Thailand, Indonesia, and Malaysia "Polish Journal of Management Studies, Vol. 6 No. 1, PP. 154-164.

Bhatia, K., and Sitlani, M., (2016), "Determinants of Capital Structure of Small Firms: Empirical Evidence from Pharmaceutical Industry in Indore "Anvesha Journal, Vol. 9 No. 3, PP. 17-28.

Cahyono B. and Chawla S., (2019), "Capital Structure Determinants of Indonesian Mining Companies: An Evidence form Balanced Panel Data". International Journal for Innovative Research in Multidisciplinary Field, Vol. 5No. 5, PP. 40-49. 